The Changi ng Nat ure of Empl oyment and the Ref or m of Labor and Social Security Legi sl at i on in Post-Apartheid South Africa

\begin{tabular}{|l|l|}
\hline 著者 & Naki no Kum ko \\
\hline 権利 & $\begin{array}{l}\text { Copyr i ght s 日本貿易振興機構 (ジェトロ } \text { ア アジア } \\
\text { 経济研究所 / I nst i ut e of Devel opi ng } \\
\text { Econom es, Japan Ext er nal Tr ade Organi zat i on } \\
\text { ( I DE- JETRO) ht t p: //www. i de. go. j p }\end{array}$ \\
\hline $\begin{array}{l}\text { j our nal or } \\
\text { publ i cat i on ti t e }\end{array}$ & I DE Di scussi on Paper \\
\hline vol une & 140 \\
\hline year & 2008 03 01 \\
\hline URL & ht t p: //doi . or g/10. 20561/00038022 \\
\hline
\end{tabular}




\title{
INSTITUTE OF DEVELOPING ECONOMIES
}

IDE Discussion Papers are preliminary materials circulated to stimulate discussions and critical comments

IDE DISCUSSION PAPER No. 140

\section{The Changing Nature of Employment and the Reform of Labor and Social Security Legislation in Post-Apartheid South Africa}

Kumiko MAKINO*

March 2008

\begin{abstract}
This paper tries to understand the current status of South African labor market, which is changing in contradictory directions, i.e. a strengthening of the rights and protection of workers at the same time as the flexibilization of employment, in the context of the characteristics of labor and social security legislation in South Africa, as well as the nature of labor and social security reforms after democratization. We put emphasis on the corporatist nature of labor policy-making as the factor influencing the course of reforms; it is argued that the apparently contradictive changes can be explained consistently by the corporatist labor policy-making process which has been practiced notwithstanding the problem of representativeness.
\end{abstract}

Keywords: South Africa, labor market, social security, corporatism JEL classification: I38, J21, J30, J50, J65

* Research Fellow, African Studies Group, Area Studies Center, IDE (makino@ide.go.jp) 
The Institute of Developing Economies (IDE) is a semigovernmental, nonpartisan, nonprofit research institute, founded in 1958. The Institute merged with the Japan External Trade Organization (JETRO) on July 1, 1998. The Institute conducts basic and comprehensive studies on economic and related affairs in all developing countries and regions, including Asia, the Middle East, Africa, Latin America, Oceania, and Eastern Europe.

The views expressed in this publication are those of the author(s). Publication does not imply endorsement by the Institute of Developing Economies of any of the views expressed within.

\section{INSTITUTE OF DEVELOPING ECONOMIES (IDE), JETRO}

\section{3-2-2, WAKABA, MIHAMA-KU, CHIBA-SHI}

\section{CHIBA 261-8545, JAPAN}

(C)2008 by Institute of Developing Economies, JETRO 


\title{
The Changing Nature of Employment and the Reform of Labor and Social Security Legislation in Post-Apartheid South Africa ${ }^{1}$
}

\author{
Kumiko MAKINO
}

The struggle against apartheid in South Africa reached its peak in the 1980s, as more and more people were mobilized through trade unions, religious organizations, residents' associations called “civics," and other civil society organizations all over the country. The mobilization for the struggle spread so widely that the National Party government was no longer able to suppress the movement by force. The criticism of apartheid from the international community heightened as well, and economic sanctions against South Africa were implemented by major countries from the mid-1980s, severely affecting the South African economy and making the cost of maintenance of the apartheid system prohibitively high. As a result, the government made a decision to initiate negotiations with the anti-apartheid forces, released Nelson Mandela, and lifted the ban on the African National Congress (ANC) and other liberation movements in 1990. After prolonged negotiations, the first non-racial general elections were held in 1994, and the transition from an apartheid regime to democracy was realized.

The labor movement played a significant role in the anti-apartheid struggle in the 1980s as well as in the negotiation process in the early 1990s (Adler and Webster 2000). The role of the Congress of South African Trade Unions (COSATU), the biggest labor organization, established in the mid-1980s, was of particular importance. Although it was not a direct ally of the ANC in the 1980s, COSATU supported the Freedom Charter, and its activism concerned not only bread-and-butter issues but also political liberation.

\footnotetext{
1 This paper is a translated and edited version of my article, "Minami-Afurika ni okeru Hi-seiki-koyo no Zoka to Rodo-ho Shakai-hosho Seido Kaikaku (in Japanese),” in Koichi Usami ed. Shinko Kogyo-koku ni okeru Koyo to Shakai-hosho [Transformation of Employment and Social Security in the Newly Industrializing Countries], Kenkyu sosho (IDE Research Series) No.565, Chiba: IDE-JETRO, 2007, pp.147-181. The original article was submitted in February 2007, and developments since then are not reflected in this paper.
} 
After the removal of the ban on the ANC, COSATU formally allied itself with the ANC and the South African Communist Party (SACP). These three organizations form the tripartite alliance through which the ANC has overwhelmingly won three general elections since 1994. In the labor law reforms in the post-apartheid era, COSATU has succeeded in winning significant protection of workers by use of its political influence in the new government.

At the same time, destabilization of employment has also taken place recently. Since the beginning of the political transition, South Africa has been rapidly integrated into the global economy, and there has been strong pressure on the South African labor market in the direction of flexibilization and deregulation. As was typically seen for African mineworkers who worked on a contract basis, flexible and insecure employment has been practiced for a long time in South Africa. In addition to the classical type of non-standard employment, there is a growing trend towards outsourcing employment, avoiding direct employment relations by utilizing labor brokers and "independent contractors" (Bezuidenhout et al. 2004; Kenny and Webster 1999; Theron and Godfrey 2000; Theron et al. 2005; Webster and Von Holdt 2005). Social protection for workers in non-standard employment is significantly inferior compared to workers in standard employment, due to the insecure nature of employment as well as the lack of social security arrangements associated with employment such as medical schemes and retirement provisions.

This paper tries to understand these changes that are taking place simultaneously in opposite directions in the context of the characteristics of labor and social security legislation in South Africa, as well as the nature of labor and social security reforms after democratization. We put emphasis on the corporatist nature of labor policy-making as the factor influencing the course of reforms. Specifically, we will focus on the process of the reforms of labor and social security legislation which have been carried forward through consensus-making between the government, business and labor representatives at the National Economic Development and Labour Council (NEDLAC). As for the definition of corporatism, the two most well-known conceptualizations are that of Schmitter $(1979=1984)$, who defined corporatism as a system of interest representation and intermediation, and that of Lehmbruch $(1979=1984)$, who saw corporatism as an institutional pattern of policy-formation; we will follow the latter definition and understand corporatism as a process of policy-making and implementation where large interest groups cooperate with each other and with public 
authorities. NEDLAC was established in 1995 as a platform for "social dialogue" between the representatives of government, business, labor and community. As of 2007, organized business is represented by the Business Unity South Africa (BUSA), and organized labor by the three main labor federations in South Africa: COSATU, the National Council of Trade Unions (NACTU), and the Federation of Unions of South Africa (FEDUSA). It is a unique feature of NEDLAC that, in addition to the conventional tripartite partners, it includes the community constituency, which is represented by national organizations of civics, youth, women, disabled people and so on. The role of the community constituency, however, is limited because it takes part in only the Development Chamber out of the four chambers of NEDLAC: Development, Trade and Industry, Public Finance and Monetary Policy, and Labor Market.

According to the NEDLAC Act, NEDLAC considers and seeks to reach consensuses about "all proposed labour legislation relating to labour market policy before it is introduced in Parliament" as well as "all significant changes to social and economic policy before it is implemented or introduced in Parliament” (Section 5). In fact, not all significant socio-economic policy changes have been considered at NEDLAC before being introduced, as is exemplified by the process of the introduction in 1996 of an important macroeconomic strategy, Growth, Employment and Redistribution (GEAR), in which NEDLAC played no role. However, as for changes in labor legislation, for which discussions by NEDLAC are mandatory before submission to Parliament, policy- making has been based on consensus reached between government, business, and labor. ${ }^{2}$ The contents of labor law reform in the post-apartheid era therefore reflect points of compromise between organized business and labor, balancing the flexibility of the labor market, which is preferable for business, and the protection of workers' rights, which is the central demand of labor. The balance taken, however, has been between the interests of organized workers and their employers, and not a result of the process where "all key stakeholders in the South African society and economy" are ensured effective participation in the formulation of policy, as was envisioned when NEDLAC was established. ${ }^{3}$ In a society like South Africa, where the

\footnotetext{
${ }^{2}$ Not all consensuses were made through formal NEDLAC processes, some being reached through bilateral negotiations between organized business and labor, as well as other various informal consultations.

3 Speech of Labour Minister Tito Mboweni at the second reading debate of the National Economic Development and Labour Council Bill at the National Assembly, 14 November 1994, Debate of the
} 
unemployment rate is extremely high and the unionization rate of workers in non-standard employment is low, the representativeness of organized labor participating in corporatist mechanisms becomes problematic (Buhlungu 2006; Webster 2006). What is important for the theme of this paper is that organized labor and business do have a corporatist means for their interests to be reflected in policies, while unemployed and unorganized workers have no such means. Corporatism has been criticized in South Africa for its undemocratic nature due to the centralization of power in a small number of elites as well as the risk of marginalization of unorganized vulnerable people (Von Holdt 1993). It was against this backdrop that the community constituency was included in NEDLAC to increase its inclusivity. However, as stated above, the community constituency participates only in the Development Chamber, and does not engage in labor policy making.

Our central argument is that the apparently contradictive changes--labor policy reform in the direction of better protection of workers' rights, and the increase in flexible and insecure employment--can be explained consistently by the corporatist labor policy-making process which has been practiced notwithstanding the problem of representativeness. The remainder of this paper will demonstrate our argument by examining how the working conditions and social security of workers in non-standard employment have been dealt with in the series of labor and social security reforms in the post-apartheid period. This paper is structured as follows. Section 1 will summarize major arguments concerning the South African labor market and the increase of non-standard employment (flexibilization and informalization). Section 2 will describe the outlines of South African labor and social security legislation and show how workers in non-standard employment are positioned within them. Section 3 examines the process of labor and social security reforms in the post-apartheid period and argues that, although the protection of workers' rights has been generally strengthened, the significance of reforms for workers in non-standard employment has been limited. Finally, we will conclude by examining the factors that have led to the delay of reforms concerning workers in non-standard employment.

National Assembly (Hansard), p.4273. 


\section{Characteristics of the South African Labor Market and Transformation of Employment Relations}

The South African labor market is evaluated by some as rigid and by others as flexible. It is regarded as rigid if the focus is on high wages due to strong trade unionism and the centralized collective bargaining system (Moll 1996), yet it is seen as flexible in terms of the high rate of non-standard employment (Standing et al. 1996). Diagnosis and prescriptions for problems with the labor market differ depending on which aspects are focused on; some would argue the rigidity of the labor market is the cause of the high unemployment rate and thus flexibilization of the labor market is necessary for job creation, yet others would argue it is the poor working conditions of workers in non-standard employment that is problematic and the policy challenge is how to strengthen and widen worker protection. The former argument is supported by organized business while the latter is supported by labor, and the dispute is as ideological as it is factual.

According to the Labour Force Survey (LFS), the unemployment rate in South Africa is above 25\% even according to the official definition; if including discouraged work seekers, over $40 \%$ of the labor force is unemployed (Statistics South Africa 2006). The unemployment rate differs according to race and gender; the highest being for African women, and the lowest for white men. Since unemployment is closely related to poverty (Bhorat et al. 2001), the extremely high unemployment rate has attracted the attention of many scholars. Job creation and poverty alleviation are also top priorities for the South African government, which has set a goal of halving unemployment and poverty by 2014 in its policy document, Accelerated and Shared Growth Initiative for South Africa (ASGISA), published in 2006.

There are various analyses of the factors of the high unemployment rate in South Africa. Bhorat points out that the absolute number of those in employment is increasing yet the unemployment rate rises because the pace of new participation in the labor market overwhelms the increase in employment (Bhorat 2004; Bhorat and Oosthuizen 2006). From political and institutional points of view, strong trade unionism and labor market regulations have been blamed for pushing up wages and thus for the high unemployment rate. What is characteristic of the labor market regulations in South Africa is the collective bargaining system; basic working conditions such as minimum 
wages and social security are determined at bargaining councils (previously called industrial councils), which are permanent collective bargaining institutions established by employer and employee organizations in a specific industry, and the agreements made there bind not only the members of bargaining councils but also parties in the same industry who do not participate in the negotiations. It has been argued that such a centralized bargaining system has the effect of pushing up wages and has hindered job creation, especially in small- and medium-sized enterprises (Moll 1996). At the same time, however, there are objections to arguments that claim the rigidity of the labor market is the main reason for the high unemployment rate, focusing instead on problems of industrial structure and its low capacity for employment absorption (Hirsch 2005: 174-184; Hirano 1999; Rodrick 2006).

Another dimension of the labor market appears if we go beyond the dichotomy of employed and unemployed, and pay more attention to various ways of working. The policy challenge of the reduction of unemployment and job creation is mainly about the quantity of employment; meanwhile the problem of non-standard employment, which is the theme of this paper, is more concerned with the quality of employment. So far, the problem of the quality of employment has been largely ignored compared to that of the quantity of employment. However, the issue of quality of employment is important as non-standard employment is increasing in South Africa, just as elsewhere in the world, against the backdrop of globalization.

This change however is difficult to grasp through statistics. Official figures regarding non-standard employment, such as terms of employment (permanent or not), became available only after 2000 when Statistics South Africa started to publish LFS, and even after the introduction of LFS, there are criticisms that the questionnaires are not adequate to grasp the reality of employment conditions and tend to underestimate the scale of non-standard employment. For instance, the estimated number of temporary workers according to LFS March 2003 was 167,486, which is less than half of the estimate made by an association of labor brokers, the Confederation of Associations of Private Employment Sector (CAPES) (Theron el al. 2005: 9-11).

Therefore, there is a limit to how far the real scale of non-standard employment can be grasped through statistical data, yet there is a consensus among the government, labor, and business sectors that the non-standardization of employment is progressing. At the Growth and Development Summit in 2003, NEDLAC constituencies agreed that 
engagement would be required as to "measures to promote decent work and to address the problem of casualisation" (NEDLAC 2003: 29), after which the "changing nature of work and atypical forms of employment” became one of the items on the agenda at the Labor Market Chamber of NEDLAC.

As for the informal sector, although it is an accepted notion that the South African informal sector is relatively small compared to other countries of a similar economic level (Kingdon and Knight 2004), it has been pointed out that recently the informalization of employment is progressing in parallel to the flexibilization of employment (Valodia 2001). Casale et al. (2004), who analyzed the trend of the informal sector from 1995 to 2003, while agreeing with Bhorat's finding that the absolute number in employment is on the rise, points out that more than $60 \%$ of the employment increase in the period was in the informal sector. Bezuidenhout et al. (2004) summarizes the phenomenon of the non-standardization of employment in South Africa as a combined effect of casualization (increase in temporary and part-time employment), externalization (outsourcing, subcontracting, and utilization of labor brokers) and the informalization of employment, which suggests that flexibilization and informalization are not two different phenomena, but are deeply related to each other, drastically changing the quality of employment in South Africa. When we refer to workers in non-standard employment in this paper, we mean not only workers in the formal sector who do not work full-time on a permanent basis, but also include externalized workers and workers in the informal sector.

Diagnosis and prescriptions for the problems of the South African labor market inevitably differ depending on whether we focus on the quantity or quality of employment. For those who claim that the labor market regulations are the principal cause of the high unemployment rate, deregulating the labor market is desirable for job creation, lowering of the unemployment rate, and poverty reduction. Such a diagnosis has been repeatedly proposed by the business sector. The typical example is "Growth for All”, a document published by the South African Foundation in 1996, which asserted that "the South African labour market is one of the most rigid in the world" and the high wages for unionized workers are sustained by the "Continental-type industrial relations systems" which prevent the creation of low-wage jobs. Therefore, the document argued for a two-tier labor market in which, besides the existing high-wage capital-intensive sector, a free entry flexible wage sector with minimum labor standards would be allowed (South African Foundation 1996: vii). 
As a counterargument, the labor constituency of NEDLAC published "Social Equity and Job Creation," which asserted that it was retrenchment and overhasty trade liberalization that were the causes of increased unemployment, and argued for more protection of workers' rights, as well as job creation and redistribution through budgetary measures (COSATU et al. 1996). Such an argument against deregulating the labor market by trade unions has been often criticized as based on the self-interest of organized workers. For instance, Seekings and Nattrass (2005) depict the situation where the interests of organized workers and the unorganized unemployed are different and the former has managed to protect and promote their interests at the expense of the latter. According to Seekings and Nattrass, the line which separates "insiders" and "outsiders" has changed since the end of 1970s, from race (whites as insiders and blacks as outsiders) to class (those with jobs as insiders and whose without jobs as outsiders). With democratization, all racial discrimination in legislation was eliminated, yet it did not mean the coming of an egalitarian society. Some blacks were now included in the insiders, yet the majority of blacks were left excluded, and the unequal nature of society remains the same.

The picture Seekings and Nattrass present is rather dichotomist in its way of categorizing participants in the labor market into insiders and outsiders; those who have jobs being insiders and those who do not being outsiders. They depict insiders typically as organized workers who enjoy relatively high wages and stable employment, and not workers in non-standard employment. This is not unreasonable considering that their focus of analysis is more on historical rather than contemporary aspects of inequality and unemployment; i.e. the characteristics of the "distributional regime" which was shaped under apartheid but maintains its influence even now. "Distributional regime" is a concept originated by Seekings and Nattrass. Based on Esping-Andersen's concept of "welfare regime," they construct the concept of "distributional regime” as consisting of economic policy (growth path strategies), labor market institutions, and redistribution through taxation and cash transfer, and argue that the "distributional regime” shapes the distributional outcome of the society. Their concept put more emphasis on the influence of labor market institutions on distributional outcome than that of Esping-Andersen's. Although their analysis is mostly historical, they give one chapter over to the post-apartheid distributional regime and argue that the interests of organized labor, especially COSATU, are more easily reflected in policies, while those of unorganized unemployed and the poor are not. As a result, labor market deregulation does not 
progress and therefore job creation is hindered (Seekings and Nattrass 2005).

Nonetheless, if we focus on the increase of non-standard employment, a somewhat different view from the dichotomist views of the employed and unemployed are required. Von Holdt and Webster (2005) argue that, as a result of work restructuring against the backdrop of globalization, the post-apartheid South African labor market can be categorized into three zones, which they respectively call core, non-core, and periphery. Included in the "core” zone are full-time workers in the formal sector, similar to the "insiders" of Seekings and Nattrass; the "non-core" zone, which lies just outside of the "core" zone, includes outsourced, temporary, part-time, and domestic workers; workers in the informal sector and the unemployed are in the "periphery" zone which is at the outer edge. The increase in non-standard employment is understood in this schema as an expansion of the "non-core" zone (shrinkage of the "core" zone) and marginalization of employment (a shift of employment from "core” to "non-core” and from "non-core" to "periphery"). From this schema, what is depicted as problematic is the difference in terms of workers' rights and protection depending on which zone one is located in. While workers in the "core” zone enjoy stable employment and relatively high wages, the jobs of "non-core” workers are generally unstable and low-waged, and, although their rights as workers have improved on paper through the series of labor law reforms, they seldom enjoy practical protection of their rights. The increase in "non-core" workers in turn threatens the working conditions of "core" workers (Von Holdt and Webster 2005: 29). In such an understanding, the goal to be sought is an expansion of protection and rights which "core" workers are enjoying to "non-core” and "periphery" workers and a reduction in the difference in levels of protection between the zones, rather than a deregulation of labor market and a further erosion of the "core" zone. This is basically in line with the position of organized labor.

In sum, organized business asserts that the current labor market regulation hinders job creation; while organized labor argues for more protection of workers. As stated above, the difference between the two is almost ideological and agreement is never reached. This paper does not intend to integrate or find a compromise between these different positions; our interest is in how non-standard employment has increased, and how and to what extent labor and social security reform for workers in non-standard employment has progressed against the backdrop of the contradicting positions of organized business and labor. 


\section{Non-Standard Employment in Labor and Social Security Legislation}

This section outlines the current South African labor and social security legislation and how workers in non-standard employment are dealt with within the legislation, as preparation for the next section, which examines post-apartheid labor and social security reform with a focus on workers in non-standard employment. Generally speaking, although there are some exceptions, workers in non-standard employment and standard employment are treated equally. However, the effectiveness of regulations differs, and the actual level of rights and protection which workers in non-standard employment enjoy is significantly inferior to that for workers in standard employment.

\subsection{Non-standard employment and labor legislation}

The two most basic South African labor laws are the Labour Relations Act (LRA) and the Basic Conditions of Employment Act (BCEA). LRA is concerned with labor relations in general, including the rights of trade unions, collective bargaining, strikes and lockouts, unfair labor practices, and procedures for labor disputes, and regulates the collective bargaining institutions called bargaining councils (BC), in which registered trade unions and employers' organizations negotiate for basic working conditions for a specific industry. If the trade unions and employers' organizations which are members of a BC are sufficiently representative of the sector, collective agreements at the BC bind non-parties within the same sector. The history of LRA dates back to 1924 when the centralized collective bargaining system through industrial councils (IC) was introduced by the Industrial Conciliation Act. Despite the change in name, the functions of IC and BC are basically the same.

There is no unified minimum wage in South Africa, sectoral minimum wages being set by BC agreements. BCEA establishes unified minimum standards as to working time, payment for overtime work, paid leave and so on, yet most of the standards can be varied downwards if there are BC agreements. For sectors not covered by BCs, the Minister of Labour can determine the basic conditions of employment such as minimum wage, working time, paid leave, and conditions of termination of employment. So far 
such sectoral determinations have been made, for instance, for domestic workers, farm workers, and contract cleaning.

Except that certain regulations of BCEA, such as those on working time, are not applied to employees who work for an employer for less than 24 hours a month, BCEA and LRA are equally applied to workers in standard employment and non-standard employment. BC agreements and sectoral determinations by the Labour Minister are also applied equally. However, as we will see in more detail in the next section, there are problems of effectiveness of labor regulations, especially for those in non-standard employment.

\subsection{Non-standard employment and social security}

The social security system in South Africa is characterized by its dual character; on the one hand, private retirement provisions (pension funds and provident funds) and medical schemes are highly developed, and on the other hand, there is a large-scale public cash transfer system through means-tested social grants for the elderly, disabled people, and for children. The South African medical system is also dualistic and sharply divided into public and private sectors. The medical standards of private hospitals are quite high though treatment is costly; free treatment is available for poor people at public health facilities, yet these are generally understaffed and waiting times tend to be quite long.

As for compulsory statutory insurance, there are Unemployment Insurance and Compensation for Occupational Injuries and Diseases. All employees have to be registered for the Unemployment Insurance Fund (UIF) except for workers working for an employer for less than 24 hours a month, learners (apprentices), public servants, foreigners working on contract, workers receiving a state old age pension, and workers who only earn commission. If workers are injured, disabled, killed, or become ill, they receive compensation from the Compensation Fund, except for workers who are totally or partially disabled for less than three days, domestic workers, anyone receiving military training, members of the South African National Defence Force or South African Police Service, any worker guilty of willful misconduct, unless they are seriously disabled or killed, anyone employed outside South Africa for 12 or more continuous months, and workers working mainly outside South Africa and only 
temporarily employed in the country. While both employers and employees contribute to the UIF, contributions to the Compensation Fund are made only by employers. Although not compulsory, provisions for private pensions and medical schemes for employees are in general included in BC agreements.

According to an estimate by the National Treasury (2004), between $66 \%$ and $84 \%$ of formal sector workers participate in private retirement provisions schemes. Participation levels for medical schemes is lower because some employees (especially if their wage is not high) choose not to be enrolled in medical schemes due to the high cost and considered low benefit. ${ }^{4}$ There are significant differences in the coverage of retirement provisions and medical schemes for workers in standard and non-standard employment in the formal sector. According to an ILO study, while $69.1 \%$ of regular workers of 340 manufacturing firms are covered by pension funds, only $23.5 \%$ of part-time workers and $8.9 \%$ of temporary workers are covered. The figures for medical schemes are respectively $74.9 \%, 30.3 \%$, and $11.1 \%$ (Standing et al 1996: table 9.2). It is reported that temporary workers are often not registered for the UIF and the Compensation Fund, in spite of it being compulsory for employers to do so (Department of Labour 2006: 6.11). Furthermore, there is no social security associated with employment for independent contractors and workers in the informal sector. Therefore, most workers in non-standard employment end up being dependent on the public social security system.

\section{Labor and Social Security Reform and Non-standard Employment}

\subsection{Strengthening of workers' rights and protection through labor law reform}

After democratization, the South African government pursued economic liberalization, as was symbolized by the introduction in 1996 of the new macroeconomic strategy, GEAR. As a point of departure, GEAR noted the necessity for greater labor market flexibility for transformation towards a competitive economy that could yield economic growth of $6 \%$ per annum. At the same time, however, it was noted

\footnotetext{
${ }^{4}$ Interview with Mr. Thulani Lucas Mthiyane (National Engineering Sector Coordinator, National Union of Metalworkers of South Africa: NUMSA) on October 30, 2006.
} 
that the extension of basic rights to a broader pool of the work force should be done in parallel with flexibilization of the labor market to facilitate employment creation (Department of Finance 1996: 1.3, 2.3). The core task of labor market reform has been to strike a delicate balance between flexibilization and workers' protection, which can be summed up as "regulated flexibility" (Department of Labour 1996). Since the starting point for the labor market reform was apartheid legislation, strengthening workers' rights and protection, rather than flexibilization, has progressed more in the process of reform as a whole.

In the apartheid era, African workers were excluded from the definition of "employee" and prohibited from forming trade unions and participating in collective bargaining. This was changed by amendments to labor legislation after the Wiehahn Commission report at the end of 1970s, which recommended that Africans should be allow to register trade unions, leading to labor movement intensification in the 1980s. However, politicized trade unions which had strong links with anti-apartheid movements were harshly oppressed, and many trade union leaders were arrested and detained. The right to strike without fear of being dismissed was only established by the introduction of the new LRA in 1995 (Bendix 2004: 83).

The LRA was among the important items of legislation which were enacted soon after democratization, and one of the first items that NEDLAC dealt with (NEDLAC 2005:34). There were many points of issue which labor and business disputed, yet as a whole, the Act reflected more of the demands of labor than those of business (Baskin and Satgar 1996; COSATU Parliamentary Office 2000: 21-27). In the background of such speedy enactment of LRA was the fact that the representatives of government, labor, and business had agreed as early as 1990 to the principle that a new LRA would be drafted upon extensive consultation and with the consensus of labor and business. ${ }^{5}$ Policy making based upon consensus-seeking among stakeholders was not practiced before the democratic transition; under apartheid regime, black people were excluded from political power, and, even among whites, there was increasing centralization of power to the executive branch of the government and marginalization of the parliament during the political crisis of the 1980s. The apartheid government did listen to the

\footnotetext{
${ }^{5}$ Minute of a Meeting between Representatives of the Working Party and the Minister of Manpower Held at the Office of the Minister in Pretoria on 13 and 14 September 1990 (Laboria Minute), accessed at the COSATU Archive (Johannesburg) in October 2006.
} 
opinions of white interest groups, yet decision-making in the late-apartheid period was characterized by secrecy and authoritarianism, and consensus among stakeholders was not sought even for important policy changes (Houston et al. 2001).

COSATU, which was formed in the mid-1980s with mostly black members, moved for the formation of a corporatist forum once the negotiation for transition started in 1990, so that the government at the time would not change important socio-economic policies unilaterally before the transition took place (Habib 1997; Webster and Adler 1999; Maree 1993). It was the labor movement that took the initiative, yet organized business also found some merit in the proposals for the sake of stabilization of labor relations against the backdrop of potential racial tensions at workplaces where employers were mostly white and employees were mostly black (Friedman and Shaw 2000). Against such a background, the National Economic Forum and the restructured National Manpower Commission were formed during the negotiation process, based on which NEDLAC was formed after the transition took place.

In the process of the establishment of the new LRA, there were some minor amendments during the parliamentary committee, yet the amendments were not substantial and the NEDLAC agreements were respected. As stated above, it is obligatory for NEDLAC to consider and seek to reach consensuses about all proposed labor legislation before it is introduced in the Parliament. Agreements reached at NEDLAC do not have legal binding force, yet there is an unwritten rule that Parliament respects the agreements and does not make significant amendments. This is a salient feature of labor policy making in South Africa, and all the new labor legislation and amendments after democratization have basically followed the same process; i.e., firstly, the government prepares draft bills, and secondly, the representatives of organized business and labor discuss and reach consensus and compromise in the Labour Market Chamber of NEDLAC or at other forums, ${ }^{6}$ and lastly the bill is introduced in the Parliament, which passes the bill into law without major amendments.

More developments followed the new LRA for strengthening workers rights and protection. The new constitution, which was enacted in 1996, established workers' rights to form and join trade unions, to strike, and to engage in collective bargaining,

\footnotetext{
${ }^{6}$ There were some cases where negotiations outside of NEDLAC were important. For instance, amendments to LRA and BCEA in 2002 were based on bilateral negotiation between business and labor at the Millennium Labour Council, and not the tripartite negotiation at NEDLAC.
} 
which are rights that everyone should enjoy without exception as they are part of the Bill of Rights. The new BCEA in 1997 set the minimum working conditions for all kinds of workers including domestic workers and farm workers, who were excluded in the previous BCEA. Except that certain provisions are not applied to employees who work for an employer for less than 24 hours a month, BCEA is applied equally to workers in both standard and non-standard employment, and rights and protection for part-time workers were extended compared to the previous BCEA. In 1998, two further important items of labor legislation, the Employment Equity Act, which includes provisions about affirmative action for blacks, women and disabled people, and the Skills Development Act, aiming to improve skill levels of workers, were enacted. Through these reforms and the introduction of new legislation, South African labor regulations as a whole have shifted towards the extension of protection for workers who had been previously excluded.

\subsection{Expansion of the social safety net}

The Bill of Rights of the new constitution established that everyone has the right to access to "social security, including, if they are unable to support themselves and their dependants, appropriate social assistance” (Section 27(1)). Similar to labor legislation, reform of the social security system has also progressed towards the extension of protection for people who were excluded from the social safety net under the apartheid regime.

Firstly, there was a reform of social grants for children in 1998. Social grants for children at that time were discriminatory and African households were virtually excluded from access to them. The newly introduced Child Support Grant was equally accessible for households of all races, and the number of recipients rapidly increased. By 2006, the total number of recipients of social grants including the Old Age Grant, Disability Grant and Child Support Grant became more than 10 million (Manuel 2006).

Another important reform concerned Unemployment Insurance. By the new Unemployment Insurance Act, which was enacted in 2001, employers are now obliged to register domestic workers and seasonal workers for the UIF. Seasonal workers are by definition non-standard employment, and although not all domestic workers are non-standard employment, Von Holdt and Webster (2005) regarded them as "non-core" 
workers due to their extreme employment vulnerability. Therefore the Unemployment Insurance reform meant extension of social security for workers in unstable and vulnerable employment. However, this does not serve as income security for the long-term unemployed and those who have been never registered for the UIF, because unemployment benefits cover only those who have contributed to the UIF, and are paid only for a limited period. As an additional means to address the issue of income security for the unemployed, the government introduced a new public works program in 2004 with a target of reaching 1 million people in five years. Access to the public works program is not a "right" of unemployed people, however, but the scale and locations of programs are determined according to budget constraints and necessity for projects.

As Unemployment Insurance is under the jurisdiction of the Department of Labour, the contents of its reform were shaped through the NEDLAC process of consensus making. Meanwhile, social grants are under the jurisdiction of the Department of Social Development. Civil society organizations, including trade unions, churches, NGOs, and social movements did engage in policy discussion about social grant reforms, yet it was mainly through lobbying the government and ANC as well as utilization of the mass media that they were carried through, and the role of NEDLAC was limited. The decision making concerning social grant reforms has been made mainly by the government, and the opinions of labor, business, other civil society organizations and experts are only used as reference and do not bind government's decisions (Makino 2005). This is in contrast with the labor law reforms, where consensus of business and labor is required for any kind of change.

\subsection{Limits of reforms, focusing on workers in non-standard employment}

We have seen in previous sections that the labor and social security reforms after democratization were basically in the direction of strengthening and extending the protection and rights of workers in general. However, to have rights on paper and to enjoy the rights in reality are two different things. This is especially so for workers in non-standard employment.

Firstly, labor legislation is only applied to those who are "employed," and not to independent contractors who provide labor and services on contract. In fact, it is not always easy to distinguish between employment and service contracts, and firms often 
prefer, even for same kind of work, to have service contracts with workers rather than employ them, so that labor legislation would not apply. As a response to this problem, LRA and BCEA were amended in 2002 so that any person who works for another person is presumed to be an employee, regardless of the form of contract, as long as the person is subject to the control or direction of the other person in terms of the manner in which the person works or hours of work, or the person is economically dependent on the other person for whom he or she works.

LRA establishes that it is regarded as dismissal if an employee reasonably expected the employer to renew a fixed-term contract of employment on the same or similar terms, but the employer offered to renew it on less favorable terms, or did not renew it (Section 186(1)(b)). However, it is not difficult for an employer to force an employee to accept a contract which would not allow the employee to reasonably expect the employer to renew the contract on the same or similar terms. Temporary workers are vulnerable because of the complexity of employment relations and the difficulties involved in monitoring compliance. Theron et al. (2005: 29-31) points out that some labor brokers use contract forms with contents such as not allowing employees to have paid leave, or prohibit strikes. In addition, workers without written contracts and those who work informally and are not registered for Unemployment Insurance are more vulnerable and substantially outside of labor legislation regulations.

Secondly, as for social security reform, most workers in standard employment do have retirement provisions and to a lesser extent medical schemes as well, as we have seen above. Income security for the non-labor force population and the unemployed also improved through social grant reforms and the extension of public works programs. However, there has been little progresses in terms of social security for those who work in non-standard employment. In early 2007, the government proposed a social security reform plan that included a compulsory retirement provision and a wage subsidy for low-wage earners (Mbeki 2007; Manuel 2007). There will be consultation with various stakeholders including organized business and labor before any decisions are made, and to what extent this proposed plan would cover workers in non-standard employment is not clear. Compulsory social health insurance or national health insurance has been also on the agenda for years (Department of Health 2002; Taylor Committee 2002: ch.8), yet it is still at the discussion stage and prospects remain uncertain.

Lund (2002) points out that the social security system in South Africa does not fit 
the needs of increasing numbers of workers in non-standard employment and the informal sector, as it has developed on the premise that most workers are in standard employment and unemployment takes place only temporarily. This is a historical problem, according to Lund, because the social security system in South Africa "was designed initially to protect the white population, especially the white working class" (p.181). White workers were protected from competition with black workers and their risk of long-term unemployment or inability to find other than unstable non-standard or informal jobs was minimized by discriminatory policies in the fields of education and labor market regulations. Social grant reforms after democratization brought about a rapid increase in recipients of grants, which has played a big role in poverty alleviation (Van der Berg et al. 2006). However, those who are entitled to social grants are limited to non-labor force people (the elderly, disabled, or children), and social grant reform did not address changes in the risk structure, such as the increase in long-term unemployment and non-standard employment. Public works programs do function, to a certain extent, as income security for the unemployed, yet the employment provided through the programs is only temporary and is not accompanied by social security such as the Unemployment Insurance.

As seen above, Bezuidenhout et al. (2004) understands the increase in non-standard employment as a combination of casualization, externalization and informalization; in fact, all three of these processes do lower the effectiveness of labor regulations. The labor law reform, as a whole, strengthened workers' rights and protection, yet at the same time an increase in non-standard employment has taken place, which means an increase in workers who do not substantially enjoy rights and protections under the new labor legislation and are excluded from social safety nets. In fact, it is the lack of regulations concerning non-standard employment itself that has enabled the increase in such unstable non-standard employment. Historically, the apartheid regime, which put African workers outside of protection by labor legislation and used them as a cheap, easily replaceable labor force, did not regulate the utilization of non-standard employment. After democratization, the protection of workers' rights was strengthened, and this is on paper equally applied to non-standard workers as well, yet the utilization of non-standard employment itself has not been regulated at all up to the present. "Permanent temporary" workers are commonly observed, and there is no restriction on the type of business and period for which temporary workers can be used.

Returning to the dispute concerning whether the South African labor market is 
rigid or flexible, it can be said that it is rigid in terms of the wage level in the formal sector due to centralized collective bargaining through BCs and sectoral determinations by the Labour Minister. However, in terms of utilization of non-standard employment, the South African labor market has been quite flexible from the apartheid era to the present. If not, South African employers would not have been increasingly able to use flexible forms of labor to adapt to rapid economic liberalization. This is in contrast to many other countries where the flexibilization of employment relations were driven by deregulation of the labor market; in South Africa, labor law reform has been in the direction of the tightening of regulations, which paradoxically might have worked as an incentive for employers to use more non-standard employment so that the total labor cost would be suppressed (Department of Labour 2006: 16; COSATU Parliamentary Office 2000).

Now that several major labor law reforms have been implemented, protection of workers in non-standard employment is one of the remaining issues for the Department of Labour. The Labour Minister stated in July 2006 that "I am of the view that the labour law should cushion and mitigate the adverse nature of atypical forms of employment and lack of protection for these workers" and "any proposed changes in the law in the next decade should ideally extend protection to vulnerable workers while balancing it with the needs of small employers” (Mdladlana 2006). The Department of Labour commissioned research about non-standard employment to Theron and other academics at the University of Cape Town in 2000 (Theron and Godfrey 2000). In addition, after the NEDLAC Growth and Development Summit in 2003, four additional research projects have been commissioned and implemented. Based upon these research results, a report particularly about the issue of non-standard employment was drafted by the Department of Labour in late 2006 (Department of Labour 2006), which will be discussed further in the Labour Market Chamber of NEDLAC.

At the time of writing, it is not clear whether there will be another amendment to the labor laws. According to the various interviews with the officials of the Department of Labour, employers' organizations, and trade unions, which the author conducted in October and November 2006, negotiations were taking place on two points; the formulation of a Code of Good Practice about who should be regarded as an "employee", and the introduction of some form of regulation about labor brokering. The 
Code of Good Practice was already agreed upon and published in December 2006, ${ }^{7}$ yet the future of regulation of labor brokering is uncertain. Organized business is against further labor law amendments to include such regulation, and hold to the opinion that what is needed to protect temporary workers is the improved effectiveness of, not amendments to, the current labor laws. ${ }^{8}$ In contrast, COSATU demands tightening of regulations concerning labor brokers by labor law amendments, as well as further regulation of fixed-term contracts (COSATU 2006). As any amendment of the labor laws requires a consensus between organized business and labor, labor law amendments in that direction are unlikely to take place in near future, and if any further regulation is introduced, it is likely to be some form of self-regulation.

\section{Conclusion}

This paper has tried to understand from the nature of labor and social security reforms after democratization the current status of the South African labor market, which is changing in contradictory directions, i.e. a strengthening of the rights and protection of workers at the same time as the flexibilization of employment. Although recent labor law reforms have as a whole have strengthened the rights and protection of workers, it is workers in standard employment who have benefited most, and the merit has not been shared equally with workers in non-standard employment. Regulation concerning non-standard employment itself has not progressed much, except for the establishment of the Code of Good Practice about who is regarded as an "employee," and there is no regulation concerning the utilization of temporary workers in terms of the type of business, contract period, repeated renewal of contracts, and so on. In addition, as the basic structure of the social security system in South Africa has not changed since the apartheid era, in which it was designed to address the needs of white

\footnotetext{
7 “Code of Good Practice: Who Is an Employee,” General Notice 1774 of 2006, Government Gazette No.29445, 1 December 2006. Retrieved February 17, 2007 from http://www.info.gov.za/gazette/notices/2006/29445.pdf.

${ }^{8}$ Interview with Ms. Corinna Gardner (Chief Officer Social Policy, Business Unity South Africa) on October 23, 2006; interview with Mr. John Botha (Confederation of Associations of Private Employment Sector) on November 8, 2006.
} 
workers who were mostly in standard employment, social security for the unemployed and workers in non-standard employment remains insufficient.

Why has there not been much progress in terms of strengthening the rights and protection of non-standard workers? One answer would be that addressing unemployment, rather than non-standard employment, has been prioritized against the backdrop of the extremely high unemployment rate; yet this paper has focused on another aspect, i.e. the limits of corporatist policy making. As we have seen above, post-apartheid labor law reforms have been the consequences of consensus and compromise between organized business and labor. The issue of insufficient protection for workers in non-standard employment is a part of organized labor's agenda, yet in reality it has been the working conditions for workers in standard employment, the main constituency of trade unions, that have been the primary focus of negotiations. Trade unions have not been indifferent about organizing workers in non-standard employment; for instance, COSATU adopted the recommendation of the September Commission in 1997 that it should try to organize workers in flexible forms of employment in order to maintain its organizational base. However, there has not been much progress since then in the unionization rate of workers in non-standard employment in COSATU-affiliated trade unions (Webster 2006: 26). Although the issue of the protection of workers in non-standard employment has attracted more attention recently, it seems that the present labor legislation, which is acceptable for business because it is easy for employers to utilize non-standard employment and also for labor because the interests of workers in standard employment are protected, is the current equilibrium point reached as a result of a series of compromises between organized business and labor.

\section{References}

Adler, Glenn and Eddie Webster, eds. [2000] Trade Unions and Democratization in South Africa, 1985-1997, Johannesburg: Witwatersrand University Press.

Baskin, Jeremy [1991] Striking Back, Johannesburg: Ravan Press.

Baskin, Jeremy and Vishwas Satgar [1996] "Assessing the New LRA: A Framework for Regulated Flexibility," in J. Baskin ed., Against the Current: Labour and 
Economic Policy in South Africa, Johannesburg: Ravan Press.

Bendix, Sonia [2004] Industrial Relations in South Africa, Fifth Impression (Revised), Cape Town: Juta.

Bezuidenhout, Andries, Shane Godfrey, Jan Theron and Mmamagang Modisha [2004] "Non-Standard Employment and Its Policy Implications," Report submitted to the Department of Labour, 30 June 2004.

Bhorat, Haroon [2004] "Labour Market Challenges in the Post-Apartheid South Africa," South African Journal of Economics, Vol.72, No. 5, pp.940-977.

Bhorat, Haroon, Murray Leibbrandt, Muzi Maziya, Servaas Van der Berg and Ingrid Woolard [2001] Fighting Poverty: Labour Markets and Inequality in South Africa, Cape Town: UCT Press.

Bhorat, Haroon and Morne Oosthuizen [2006] "Evolution of the Labour Market: 1995-2002," in H. Bhorat and R. Kanbur eds., Poverty and Policy in Post-Apartheid South Africa, Cape Town: HSRC Press.

Buhlungu, Sakhela [2006] "Introduction: COSATU and the First Ten Years of Democratic Transition in South Africa," in S. Buhlungu ed., Trade Unions and Democracy: COSATU Workers Political Attitudes in South Africa, Cape Town: HSRC Press.

Casale, Daniela, Colette Muller and Dorrit Posel [2004] "'Two Million Net New Jobs': A Reconsideration of the Rise in Employment in South Africa, 1995-2003," South African Journal of Economics, Vol.72, No. 5, pp.978-1002.

COSATU (Congress of South African Trade Unions) [2006] "Declaration and Resolutions, COSATU Ninth National Congress, Gallagher Estate, Midrand, September 18-21, 2006." Retrieved February 17, 2007 from http://www.cosatu.org.za/cong2006/congress06/finresolu.htm.

COSATU, NACTU and FEDSAL [1996] Social Equity and Job Creation: The Key to a Stable Future, Johannesburg: Labour Caucus at NEDLAC, incorporating COSATU, NACTU and FEDSAL.

COSATU Parliamentary Office [2000] Accelerating Transformation: COSATU's Engagement with Policy and Legislative Processes during South Africa's First 
Term of Democratic Governance, Cape Town: COSATU Parliamentary Office.

Department of Finance [1996] "Growth, Employment and Redistribution: A Macroeconomic Strategy," Pretoria: Department of Finance. Retrieved February 17, 2007 from http://www.treasury.gov.za/documents/gear/all.pdf.

Department of Health [2002] "Policy Options for the Future Covering: Inquiry into the Various Social Security Aspects of the South African Health System - Based on the Health Subcommittee Findings of the Committee of Inquiry into a Comprehensive System of Social Security," Pretoria: Committee of Enquiry Health Chapter, Department of Health. Retrieved February 17, 2007 from http://www.doh.gov.za/docs/reports/2002/inquiry/.

Department of Labour [1996] "Minimum Standard Directorate Policy Proposals for a New Employment Standards Statute Green Paper, 13 February 1996," Pretoria: Department of Labour. Retrieved February 17, 2007 from http://www.info.gov.za/greenpapers/1996/labour.htm.

[2006] "Changing Nature of Work and 'Atypical' Forms of Employment in South Africa: Synthesis Report," Unpublished document.

Friedman, Steven and Mark Shaw [2000] "Power in Partnership? Trade Unions, Forums and the Transition," in G. Adler and E. Webster eds., Trade Unions and Democratization in South Africa, 1985-1997, Johannesburg: Witwatersrand University Press.

Habib, Adam [1997] "From Pluralism to Corporatism: South Africa's Labour Relations in Transition," Politikon, Vol.24, No.1, pp.57-75.

Hirano, Katsumi [1999] "Minami-Afurika ni okeru Tairyo Shitsugyo Mondai no Sangyo Kozo-ron-teki Bunseki (in Japanese)," [An Analysis on Mass Unemployment in South Africa: Perspective of the Industrial Structure Theory] in Katsumi Hirano ed., Shinsei Kokka Minami-Afurika no Shogeki [Impacts of New South Africa], IDE Research Series No.495, Tokyo: IDE-JETRO.

Hirsch, Alan [2005] Season of Hope: Economic Reform under Mandela and Mbeki, Pietermaritzburg: University of KwaZulu-Natal Press.

Houston, Gregory, Ian Liebenberg and William Dichaba [2001] "Interest Group 
Participation in the National Economic Development and Labour Council, " in Gregory Houston ed., Public Participation in Democratic Governance in South Africa, Pretoria: HSRC.

Kenny, Bridget and Edward Webster [1999] "Eroding the Core: Flexibility and the Re-segmentation of the South African Labour Market," Critical Sociology, Vol.24, No. 3, pp.216-243.

Kingdon, Geeta Ghandi and John Knight [2004] "Unemployment in South Africa: The Nature of the Beast," World Development, Vol.32, No. 3, pp.391-408.

Lehmbruch, Gerhard [1979=1984] "Riberaru Koporatizumu to Seito Seiji (in Japanese)," [Liberal Corporatism and Party Government] in Philippe C. Schmitter and Gerhard Lehmbruch eds. (translated by Yasushi Yamaguchi et al.), Gendai Koporatizumu (I) Dantai Togo Shugi no Seiji to sono Riron [Trends toward Corporatist Intermediation], Tokyo: Mokutakusha.

Lund, Francie [2002] "Social Security and the Changing Labour Market: Access for Non-Standard and Informal Workers in South Africa," Social Dynamics, Vol.28, No. 2, pp.177-206.

Makino, Kumiko [2005] "Minshuka-go no Minami-Afurika ni okeru Shotoku Hosho Seido Kaikaku: Shakai Teate to Kokyo Jigyo Puroguramu (in Japanese),” [Income Security Policy Reform in Post-Apartheid South Africa: Social Grants and the Public Works Programme] in Koichi Usami ed., Shinko Kogyo-koku no Shakai Fukushi [Social Protection Systems in Newly Industrializing Countries in the 21st Century], IDE Research Series No.548, Chiba: IDE-JETRO.

Manuel, Trevor A. [2006] "Budget Speech 2006 by Minister of Finance Trevor A Manuel." Retrieved $\quad$ February 17, 2007 from http://www.info.gov.za/speeches/2006/06021515501001.htm.

[2007] "Budget Speech 2007 by Minister of Finance Trevor A Manuel, MP." Retrieved May 6, Mam http://www.info.gov.za/speeches/2007/07022115261001.htm.

Mbeki, Thabo [2007] "State of the Nation Address of the President of South Africa, Thabo Mbeki: Joint Sitting of Parliament." Retrieved May 6, 2007 from http://www.info.gov.za/speeches/2007/07020911001001.htm. 
Maree, Johann [1993] "Trade Unions and Corporatism in South Africa," Transformation, No.21, pp.24-54

Mdladlana, Membathisi [2006] "Labour law in the Next Decade: Time for a Change? Speech by the Minister of Labour, M Mdladlana, at the 19th Annual Labour Law Conference, Sandton Convention Centre, 6 July 2006." Retrieved February 17, 2007 from http://www.info.gov.za/speeches/2006/06070716451003.htm.

Moll, Peter [1996] "Compulsory Centralization of Collective Bargaining in South Africa," American Economic Review, Vol.86, No. 2, pp.326-329.

National Treasury [2004] "Retirement Fund Reform: A Discussion Paper," December 2004. Retrieved February 17, 2007 from http://www.treasury.gov.za/documents/retirement/Retirement\%20Fund\%20Refo rm\%20A\%20Discussion\%20Paper.pdf.

NEDLAC (National Economic Development and Labour Council) [2003] Growth and Development Summit Agreement (GDS), Johannesburg: NEDLAC.

[2005] 10 Years of Social Dialogue: The Nedlac Experience, Johannesburg: NEDLAC.

Rodrick, Dani [2006] Understanding South Africa's Economic Puzzles, NBER Working Paper Series, Working Paper 12565, Cambridge, MA: National Bureau of Economic Research. Retrieved December 1, 2006 from http://www.nber.org/papers/w12565.pdf.

Schmitter, Philippe [1979=1984] "Ima mo nao Koporatizumu no Seiki nanoka? (in Japanese)" [Still the Century of Corporatism?] in Philippe C. Schmitter and Gerhard Lehmbruch eds. (translated by Yasushi Yamaguchi et al.), Gendai Koporatizumu (I) Dantai Togo Shugi no Seiji to sono Riron [Trends toward Corporatist Intermediation], Tokyo: Mokutakusha.

Seekings, Jeremy and Nicoli Nattrass [2005] Race, Class and Inequality in South Africa, New Haven, CT: Yale University Press.

South African Foundation [1996] Growth for All: An Economic Strategy for South Africa, Johannesburg: South African Foundation.

Standing, Guy, John Sender and John Weeks [1996] Restructuring the Labour Market: 
The South African Challenge - An ILO Country Review, Geneva: ILO.

Statistics South Africa [2006] Labour Force Survey March 2006, Statistical Release P0210, Pretoria: Statistics South Africa.

Taylor Committee (Committee of Inquiry into a Comprehensive System of Social Security for South Africa) [2002] Transforming the Present, Protecting the Future: Consolidated Report, Pretoria: Department of Social Development.

Theron, Jan and Shane Godfrey [2000] Protecting Workers on the Periphery, Cape Town: Institute of Development and Labour Law, University of Cape Town.

Theron, Jan, Shane Godfrey and Peter Lewis [2005] The Rise of Labour Broking and Its Policy Implications, Monograph 1/2005, Cape Town: Institute of Development and Labour Law, University of Cape Town.

Valodia, Imraan [2001] "Economic Policy and Women's Informal Work in South Africa," Development and Change, Vol.32, No.5, pp.871-892.

Van der Berg, Servaas, Ronelle Burger, Rulof Burger, Megan Louw and Derek Yu [2006] Trends in Poverty and Inequality since the Political Transition, Working Paper 06/104, Cape Town: Development Policy Research Unit, University of Cape Town. Retrieved February 17, 2007 from http://www.commerce.uct.ac.za/Research_Units/DPRU/WorkingPapers/PDF_Fil es/WP06-104.pdf.

Von Holdt, Karl [1993] "The Danger of Corporatism," SA Labour Bulletin, Vol.17, No.1, pp.46-51.

Von Holdt, Karl and Eddie Webster [2005] "Wage Restructuring and the Crisis of Social Reproduction: A Southern Perspective," in E. Webster and K. Von Holdt eds., Beyond the Apartheid Workplace: Studies in Transition, Pietermaritzburg: University of KwaZulu-Natal Press.

Webster, Eddie [2006] "Trade Unions and the Informalisation of Work," in S. Buhlungu ed., Trade Unions and Democracy: COSATU Workers Political Attitudes in South Africa, Cape Town: HSRC Press, pp.21-43.

Webster, Eddie and Karl Von Holdt, eds. [2005] Beyond the Apartheid Workplace: Studies in Transition, Pietermaritzburg: University of KwaZulu-Natal Press. 
Webster, Edward and Glenn Adler [1999] "Towards a Class Compromise in South Africa's 'Double Transition': Bargained Liberalization and the Consolidation of Democracy," Politics \& Society, Vol.27, No.3, pp.347-385. 